\title{
Instrumental and ethical aspects of experimental research with animal models
}

\author{
ASPECTOS INSTRUMENTAIS E ÉTICOS DA PESQUISA EXPERIMENTAL COM MODELOS \\ ANIMAIS
}

\section{ASPECTOS INSTRUMENTALES Y ÉTICOS DE LA INVESTIGACIÓN EXPERIMENTAL CON MODELOS ANIMALES}

\author{
Mirian Watanabe ${ }^{1}$, Cassiane Dezoti da Fonseca², Maria de Fatima Fernandes Vattimo ${ }^{3}$
}

\begin{abstract}
Experimental animal models offer possibilities of physiology knowledge, pathogenesis of disease and action of drugs that are directly related to quality nursing care. This integrative review describes the current state of the instrumental and ethical aspects of experimental research with animal models, including the main recommendations of ethics committees that focus on animal welfare and raises questions about the impact of their findings in nursing care. Data show that, in Brazil, the progress in ethics for the use of animals for scientific purposes was consolidated with Law No. 11.794/2008 establishing ethical procedures, attending health, genetic and experimental parameters. The application of ethics in handling of animals for scientific and educational purposes and obtaining consistent and quality data brings unquestionable contributions to the nurse, as they offer subsidies to relate pathophysiological mechanisms and the clinical aspect on the patient.
\end{abstract}

\section{DESCRIPTORS}

Animal experimentation

Basic research

Animal Care Committees

Nursing

Review

\section{RESUMO}

Os modelos experimentais com animais oferecem possibilidades de conhecimento da fisiologia, da etiopatogenia das doenças e da ação de medicamentos que estão diretamente relacionados com a assistência de enfermagem de qualidade. Essa revisão integrativa descreve o estado atual dos aspectos instrumentais e éticos da pesquisa experimental com modelos animais, incluindo as principais recomendações dos comitês de ética que visam ao bem-estar animal e faz considerações sobre impacto de seus resultados na enfermagem assistencial. Os dados mostram que, no Brasil, o avanço na ética para o uso de animais para fins científicos consolidou-se com a Lei $n$ o $11.794 / 2008$, que estabelece os procedimentos éticos, atendendo ainda parâmetros sanitários, genéticos e experimentais. A aplicação da ética no manuseio de animais para fins científicos e didáticos e a obtenção de dados consistentes e de qualidade trazem contribuições inquestionáveis ao enfermeiro, uma vez que oferecem subsídios para se relacionar mecanismos fisiopatológicos e a clínica do paciente.

\section{DESCRITORES}

Experimentação animal

Pesquisa básica

Comitês de Cuidado Animal

Enfermagem

Revisão

\section{RESUMEN}

Los modelos experimentales con animales ofrecen la posibilidad de conocimiento de fisiología, etiopatogenia y la acción de los fármacos que están directamente relacionados con la calidad del cuidado de enfermería. Esta revisión integradora describe los aspectos instrumentales y éticos de la investigación experimental con modelos animales, incluyendo las principales recomendaciones de los comités de ética para resguardar el bienestar de los animales y las consideraciones sobre el impacto de sus resultados en la enfermería asistencial. Los datos muestran que, en Brasil, los avances en materia de ética sobre el uso de animales para fines científicos se consolidó con la Ley $N$ ㅇ 11.794/2008 que establece los procedimientos éticos que considera el cumplimiento de los parámetros sanitarios, genéticos y experimentales. La aplicación de la ética en el manejo de animales con fines científicos y educativos y la obtención de datos consistentes y de calidad, traen aportes incuestionables a la enfermería, ya que ofrecen cánones para relacionar los mecanismos fisiopatológicos y clínicos del paciente.

\section{DESCRIPTORES \\ Experimentación animal Investigación básica Comités de atención animal Enfermería Revision}

${ }^{1}$ PhD, School of Nursing, University of Sao Paulo, Sao Paulo, SP, Brazil. ${ }^{2}$ Masters, School of Nursing, University of Sao Paulo, Sao Paulo, SP, Brazil. ${ }^{3}$ Full professor, Department of Medical-surgical Nursing, School of Nursing, University of Sao Paulo, Sao Paulo, SP, Brazil. nephron@usp.br 


\section{INTRODUCTION}

The use of models to improve the knowledge about diseases and treatments is essential for the evaluation, monitoring and often healing. The development of studies to prove a hypothesis firstly determines the decision for a method to obtain results. The experimental models help the understanding of natural phenomena. It may enhance the knowledge of physiology, the pathogenesis of the diseases, the action of drugs, the results of surgery interventions and even help the confirmation of hypotheses rarely isolated in humans by the coexistence of other biological variables ${ }^{(1-2)}$.

There are several experimental models used in scientific research, since the use of animals, known as studies in vivo, and those in which use immortalized cells, known as in vivo. Among the latter, the models that stand out grow cells on plates that reproduce physiological responses and sometimes allow the formation of normal tissues or with some morphogenetic changes, allowing the interpretation of the pathophysiological mechanisms involved, even away from its origin site. In addition to biological models, there are still the mathematic models, which can be used to predict the behavior of diseases, however, they are inappropriate for the identification of biological variables involved in the health-illness process ${ }^{(1)}$.

In spite of the restrictions of handling models in vivo, they continue to provide incomparable advantages in research in the health area. In this scenario, the highlights are the treatments for coronary disease, cancer, diabetes, chronic degenerative diseases, vaccines and many others whose therapeutic advances, whether pharmacological or assistive, derived from animal models $^{(3)}$. We highlight the need for the adoption of a humanized care with animal in research, and strategies to ensure animal welfare.

Animal models are used to study morbidities or pathophysiological mechanisms of humans or animals. Animals with similar morbidities may be studied and human morbidities may be induced in animals and its results can be used to clarify the progression of a disease process or to identify critical points in its evolution. Animal models used in the study of human diseases or pathophysiological mechanisms translate into undeniable benefits, but the existence of questions regarding their applicability and validity in the transposition into clinical practice still persists in some cases ${ }^{(1-2)}$.

Currently, the use of animals in research follows guidelines established by international and national committees. Its principles are based on equal rights, which consist in the existence of animal rights, and their right to be respected by men. That said, there is consensus that animal experiments involving physical or psychological suffering is incompatible with the right of the animal, whether it is a medical, scientific, commercial or any other experiment ${ }^{(4-6)}$.

In Brazil, Law No. 11.794/2008 was sanctioned, which regulates and establishes procedures for the use of animals for scientific purposes. The Law establishes the creation of the National Council for the Control and Experimentation in Animals - CONCEA and makes mandatory the Ethics Committees on Animal Use (CEUA) in institutions with teaching or research activity in order to ensure proper care and ethical handling of animals for scientific and teaching purposes ${ }^{(7)}$.

Considering that doubts on the use of animal models still persist and that the impact of experimental research with animals in nursing care is unclear, this review aims to contribute to health research in nursing, discussing the instrumental and ethical aspects of experimental research with animal models.

\section{METHOD}

We conducted an integrative review of the literature that followed the recommended steps: formulation of the theme, establishments of inclusion and exclusion criteria, definitions of information extracted from selected studies, evaluation of studies and presentation of results ${ }^{(8)}$.

The literature review was conducted through the Virtual Health Library in the electronic databases LILACS - Latin American and Caribbean Literature on Health Sciences, IBECS - Spanish Bibliographic Index of Health Sciences, MEDLINE - International Literature on Health Sciences, Cochrane Library, SciELO - Scientific Electronic Online Libray. We used the health terminology contained in the keywords DeCS/MeSH: Pesquisa Básica/Basic Research, Experimentação animal/Animal Experimentation and Experimentation e Comitês de cuidado animal/Animal care committees. The keywords have been combined, according to the database.

The guiding question of the integrative review was How are the basic aspects of animal research models defined?. The inclusion criteria were: articles and journals available in full online, in Portuguese, Spanish and English and between the time frame 2001-2013. Studies with specific approaches that encompass pathophysiological mechanisms of diseases, basic research in vitro models and behavioral research were excluded. A total of 21 articles were selected. We proceeded to the reading of each abstract/article. The synthesis and analysis of the studies allowed the grouping of data into thematic units related to experimental research with animal models, divided into: experimental research with animal models, principles of experimental research with animal models, care and ethical handling of animals, Brazilian law, experimental research for nursing. 


\section{RESULTS}

Selected articles were listed in Chart 1 . We found predominance of national journals, with 11 articles
(52.4\%), with 2 articles from nursing journals, and 10 articles (47.6\%) from international journals originating in the United States and England. Chart 2 summarizes the main findings of each article included in the sample.

Chart 1 - Artigos selecionados, segundo autores, revista, país de origem, título e ano de publicação.

\begin{tabular}{|c|c|c|c|}
\hline $\mathbf{N}$ & Journal/Country & Title & Year \\
\hline E1 & Acta Cir Bras/Brasil & Modelos experimentais em pesquisa & 2005 \\
\hline E2 & Altern Lab Anim / Inglaterra & The origins and early days of the three Rs concept. & 2009 \\
\hline E3 & Braz J Otorhinolaryngol / Brasil & Research ethics in animal models & 2012 \\
\hline E4 & Gene Ther / Inglaterra & Use of animals in experimental research: an ethical dilemma? & 2004 \\
\hline E5 & Sci Med / Brasil & Modelos animais na pesquisa biomédica. & 2010 \\
\hline E6 & Rev Bras Cir Cardiovasc/ Brasil & Tendências em experimentação animal. & 2009 \\
\hline E7 & PloS One / Estados Unidos & $\begin{array}{l}\text { Ethical and scientific considerations regarding animal testing and } \\
\text { research. }\end{array}$ & 2011 \\
\hline E8 & Acta Cir Bras / Brasil & $\begin{array}{l}\text { Progress in animal experimentation ethics: a case study from a Brazilian } \\
\text { medical school and from the international medical literature. }\end{array}$ & 2012 \\
\hline E9 & Alter Lab Anim / Inglaterra & Reduction & 2013 \\
\hline E10 & Rev Assoc Med Bras / Brasil & $\begin{array}{l}\text { Aspectos fundamentais da experimentação animal - aplicações em } \\
\text { cirurgia experimental. }\end{array}$ & 2010 \\
\hline E11 & PloS One / Estados Unidos & Pain in laboratory animals: the ethical and regulatory imperatives. & 2011 \\
\hline E12 & Rev Bras Anestesiol / Brasil & Aspectos éticos da experimentação animal. & 2003 \\
\hline E13 & Alter Lab Anim / Inglaterra & $\begin{array}{l}\text { Animal ethics training for postgraduates in medical schools in India: } \\
\text { catch them young! }\end{array}$ & 2013 \\
\hline E14 & Alter Lab Anim / Inglaterra & $\begin{array}{l}\text { Animal ethics training for postgraduates in medical schools in India: } \\
\text { catch them young! }\end{array}$ & 2013 \\
\hline E15 & Rev Lasallist Investig / Bolivia & $\begin{array}{l}\text { Bioética em la experimentación científica com animales: cuestión de } \\
\text { regulamentación o de actitud humana }\end{array}$ & 2012 \\
\hline E16 & Alter Lab Anim / Inglaterra & The ethics of using laboratory animals to develop medicine for lifestyle. & 2013 \\
\hline E17 & Comp Med / Estados Unidos & Animal models of cancer pain. & 2008 \\
\hline E18 & Acta Cir Bras / Brasil & Ética e experimentação animal. & 2001 \\
\hline E19 & Hist Cien Saude Manguinhos / Brasil & $\begin{array}{l}\text { A regulação do uso de animais no Brasil do século XX e o processo de } \\
\text { formação do atual regime aplicado à pesquisa biomédica. }\end{array}$ & 2010 \\
\hline E20 & Rev Lat Am Enfermagem / Brasil & As ciências básicas e a enfermagem & 2011 \\
\hline E21 & Rev Lat Am Enfermagem / Brasil & Pesquisa básica na enfermagem. & 2004 \\
\hline
\end{tabular}

Chart 2 - Summary of selected articles.

\begin{tabular}{|c|c|}
\hline $\mathbf{N}$ & Synthesis \\
\hline E1 & $\begin{array}{l}\text { Review conducted with the objective of classifying the main experimental models used in research and its possible appli- } \\
\text { cations in experimental research. Highlights classification of animals to the sanitary condition, genotype and experimental } \\
\text { model. }\end{array}$ \\
\hline E2 & $\begin{array}{l}\text { Definition of the concept 3Rs (replacement, reduction, refinement) of Russell and Burch (1959), responding to current is- } \\
\text { sues, in accordance with the principles for handling laboratory animals. }\end{array}$ \\
\hline E3 & $\begin{array}{l}\text { Literature review. Describes the use of animals in experimentation in medical research, according to current Brazilian law } \\
\text { (Law No. 11.794/08). Points out the positive aspects of research with animal models. }\end{array}$ \\
\hline E4 & $\begin{array}{l}\text { A detailed account of experimental research, with early experimental physiological studies of Claude Bernard to the present } \\
\text { day. Considers the ethical and humane handling of laboratory animals. Quantitatively analyzes, the use of various animal } \\
\text { species and the study objective. }\end{array}$ \\
\hline E5 & $\begin{array}{l}\text { Report the need for experimental research to obtain important concepts for the treatment of various diseases. Justifies and } \\
\text { reports benefits of experimental research. }\end{array}$ \\
\hline E6 & $\begin{array}{l}\text { Analysis of studies published in national journals that use animal models in order to describe the aspects related to experi- } \\
\text { mental research. }\end{array}$ \\
\hline E8 & $\begin{array}{l}\text { Presentation of an analysis of projects submitted to the Ethics Committee for animal use in the period } 2002-2009 \text {. The } \\
\text { research conducted a comparative analysis of the publications presented by the international biomedical community. Em- } \\
\text { phasized the main guidelines for publication in high impact journals, established for over } 40 \text { years as review and approval } \\
\text { by the ethics committee for animal use and compliance with ethical principles of handling laboratory animals. }\end{array}$ \\
\hline
\end{tabular}

Continued. 


\begin{tabular}{|c|c|}
\hline \multicolumn{2}{|l|}{..Continuation } \\
\hline $\mathbf{N}$ & Synthesis \\
\hline E9 & $\begin{array}{l}\text { Reinforced the need for training and education of researchers in the experimental area with animals to prepare the experi- } \\
\text { ment, based on previous studies, statistical analysis and interpretation of the results found. }\end{array}$ \\
\hline E10 & $\begin{array}{l}\text { Comprehensive review article that describes the fundamentals of animal research, especially for mouse, rat and rabbit spe- } \\
\text { cies. Discusses the standardization of experimental models, genetics, environment, safety, analgesia, euthanasia, postopera- } \\
\text { tive care and finally Brazilian legislation for the handling of laboratory animals. }\end{array}$ \\
\hline E11 & $\begin{array}{l}\text { Describes the advent of new technologies to refine the use of animals in studies, to reduce the number of animals and re- } \\
\text { place animals in large scale. Discusses the best recognition of pain and its treatment and disseminates information on "best } \\
\text { practices", including the ethical and humane handling of animals for scientific purposes. }\end{array}$ \\
\hline E12 & Description of ethical principles for the handling of laboratory animals in order to promote animal welfare. \\
\hline E13 & $\begin{array}{l}\text { Brief report for ethical handling of laboratory animals for teaching and research. Focus on training and humane handling } \\
\text { includes analgesia, sedation and euthanasia. }\end{array}$ \\
\hline E14 & $\begin{array}{l}\text { Introduction of the fourth } \mathrm{R} \text { - Rehabilitation - describes the importance of the training of all professionals for proper han- } \\
\text { dling and execution of standard practices for each species. }\end{array}$ \\
\hline E15 & $\begin{array}{l}\text { Reflection study, the major bioethical aspects of animal experimentation: the evolution of science and animal welfare. High- } \\
\text { lights the importance of ethics committees for animal use. }\end{array}$ \\
\hline E16 & $\begin{array}{l}\text { Brief report referring to the use of animals for human survival. Emphasizes the need to use animals as a food source and } \\
\text { also for scientific research that assists in the discovery of new drugs, from a humane and ethical awareness. }\end{array}$ \\
\hline E17 & $\begin{array}{l}\text { Describes new interventions for pain control in experimental induction models of neoplasms, as well as more effective } \\
\text { methods to quantify pain in animals (rats, mice). }\end{array}$ \\
\hline E18 & $\begin{array}{l}\text { Ethical reflection, which presents the main reasons for the ethical handling of animals in research. Strengthens the law and } \\
\text { respect for animals. }\end{array}$ \\
\hline E19 & $\begin{array}{l}\text { Analysis of Brazil's public and regulatory policy on the use of animals in teaching and biomedical research. Addresses the } \\
\text { legal status of the protection of animals in the country under the law } 11.794 / 2008 \text {. }\end{array}$ \\
\hline E20 & $\begin{array}{l}\text { Approach of experimental research for nursing, reinforcing that it may be a facilitator of the intersection among results of } \\
\text { basic science and assistance area. }\end{array}$ \\
\hline E21 & Literature review focusing on the integration of basic and experimental science with the everyday actions of the nurse. \\
\hline
\end{tabular}

\section{DISCUSSION}

The study conducted allowed us to describe the principles guiding research with animal models and identify issues related to established ethical procedures in the country and the world.

\section{Experimental research with animal models}

Experimental research includes studies with animals, cadavers, tissues and cell cultures ${ }^{(9)}$. In health science, these practices allow improvement on the knowledge of physiology, pathogenesis of the disease and actions of new treatments. However, in order to produce ethical and quality results, the experimental model should reproduce, as faithfully as possible, what is intended to study ${ }^{(1,9)}$.

Animal models stand out in almost all fields of biological research. The first report of experimental research on animal model was made in 1860 by Claude Bernard, known as the father of modern experimental physiology. Bernard was one of the pioneers in developing and publicly describing the advantages of reproducing animal models for the advancement of science. From his trials derived the principles of experimental biomedicine adopted today. According to him, most biomedical advances were obtained through laboratory experiments and only those developed with animals were able to faithfully reproduce the original models ${ }^{(4-5)}$.
A classic example of disregard for animal model was the assumption that penicillin could never be used in humans and that its use was restricted to a kind of laboratory animals, guinea pigs. At that time, that fact invalidated any intention to use that agent in humans. If that proposition had not been questioned and the investigation process had been permanently interrupted, penicillin would not be considered safe today and neither would have represented a milestone in the field of antimicrobial treatments ${ }^{(10)}$.

Researches in vivo are classified into four categories, according to the model of experimentation: 1) induced - situations where the condition/disease investigated is being experimentally induced; 2) spontaneous - uses genetic variants of human diseases that occur naturally in animals; 3) negative - uses animals, in which a specific disease does not develop or that demonstrate a lack of reactivity to a specific stimulus; 4) orphan - a condition which occurs naturally in animals under conditions not described in humans and later adopted when the disease is identified in humans ${ }^{(2-3)}$.

\section{The principles of experimental research with animal models}

Historically, the ethical and animal welfare aspects concerning research trials walk parallel with the evolution of experimental research. In 1959, the book entitled The principles of humane animal experimental techniques, written by William Russell and Rex Burch, in which the 
rule of the three $R$ was presented for the first time, now known and applied worldwide: replacement, reduction and refinement, which governs ethical principles in research with animals ${ }^{(4-5,11)}$.

The replacement refers to the substitution of larger to smaller animals. This guidance suggests that microorganisms, plants, eggs, reptiles, amphibians and invertebrates are preferred in research, avoiding the use of animals of hot blood ${ }^{(4,11)}$. A case study conducted in a Brazilian university demonstrated that rats and mice are the most commonly used species in experimental research ${ }^{(12)}$. Research with live animal models should consider replacing species by another of lower rank in the zoological scale, the adoption of computerized methods or in vitro models as alternative. It is noteworthy that it is not always possible the adoption of the principle of replacement and it can sometimes compromise the full reproduction of biological event because of the absence of the original environment and all physiological and pathological variables related ${ }^{(4,11)}$.

The reduction is related to the selection of the minimum number of animals per study. Presupposes conducting pilot studies to identify potential problems, the exact use of test animals and their controls, obtaining as much information as possible about the study before its initiation, previous statistical prediction of the study, minimization of environmental variables such as disease, stress and diet that may affect the results and, finally, selecting the appropriate species for that purpose ${ }^{(4,11,13)}$. The animals used in research should meet ideal conditions, ie, must be kept in controlled environment to maintain the health and genetic parameters, to ensure uniformity in relation to environmental, genetic and experimental variables $^{(2-3)}$. The sample size can be estimated by mathematical relationship between the value of the studied effect (the biologically significant difference), the standard deviation (usually obtained from a pilot), the level of significance (usually between 0.05 and 0.01 ) and power of the test (usually between 80 and $90 \%)^{(14)}$. The variability of the sample may also be reduced with standard procedures, well-defined objectives and accurate methods to measure the responses for accepting or rejecting the initial hypothesis. Another aspect to be highlighted is that the experimental results without statistical significance should also be published to ensure no redundancy of similar studies $^{(13-14)}$.

Finally, the refinement of the technique consists in the adoption of different strategies to prevent or reduce stress, pain or unnecessary suffering to animals. Even in trials where pain or stress situations are the objects of study, unusual models nowadays, comfort measures should be implemented and should never allow higher levels of discomfort to those tolerated by humans ${ }^{(4,11)}$. Animal welfare is a prerequisite for more realistic experimental results; therefore, the choice for procedures that reduce their suffering and improve their well-being through the use of analgesics and sedatives should be a priority ${ }^{(5-6)}$.

\section{The ethical care and handling of animals}

The diversity of techniques and behaviors of animal models required the elaboration of guidelines for the standardization of procedures which guarantee respect for the animal and the reliability of results ${ }^{(4,11)}$.

In Geneva, in 1985, the Council of International Organizations of Medicals Sciences established ethical standards for the development of research in animal models through the development of Principles for Biomedical Research Involving Animals that have been adopted internationally by various institutions of education and research $^{(15-16)}$. In this consensus, the main recommendations were $^{(17)}$ :

- the advancement of biological knowledge often requires the use of live animals in perfect quality and a wide variety of species;

- alternative methods should be used whenever appropriate;

- animal experimentation should be conducted only after consideration of their relevance to the health of men and animals;

- researchers and others involved in research should be imperatively ethical to avoid or minimize discomfort, pain and stress in animals.

Whereas research priority is the welfare of laboratory animals, the experimental animal rooms should have default characteristics predetermined to maintain the temperature, humidity, alternating cycles of day and night and efficient filtration for maintenance of air quality ${ }^{(6,18)}$. Still aiming to ensure animal welfare, the environment of captivity may be modified to provide stimulus for the animals to meet their needs specific-species. Examples of environmental enrichment would be accessories such as nests, tubes that serve as hiding and refuge areas for rodents and rabbits ${ }^{(6,18)}$.

The handling and surgical procedure or administration of drugs in animals should only be performed by qualified professionals. Recently, the introduction of the concept of the fourth $R$, rehabilitation, reinforces the need for training and improvement of the research team ${ }^{(19-20)}$.

The Federation of European Laboratory Animal Science Associacion (FELASA) recommends the existence of four professional categories (A, B, C and D) in research laboratories with animal models and recommends specific training for categories A, B and C. In category A, would be professional or researcher who begins his/her theoretical/practice training, and only when they acquire the lab experience, evolves on a scale of difficulty performing routine tasks in handling animals. The category $\mathbf{B}$ is necessary for professionals and researchers who perform procedures with animals and category $\mathbf{C}$ includes the professional or researcher responsible for the experiment with animals. The category D is restricted to professional or researcher with specialized training for care and handling of laboratory animals ${ }^{(18)}$. 
Currently, the experimental research conducted with animal models for educational or research purposes is mandatory to minimize the discomfort, stress and pain throughout the experiment ${ }^{(6,15,21)}$. The premise that all procedures that result in pain in humans also cause pain in other vertebrate species is always followed ${ }^{(15,21)}$. These procedures, which can cause momentary pain or distress should be performed minimally or avoided to the maximum or, in extreme case of scientific necessity, under sedation, analgesia or anesthesia. At the end of the experiment or at any time of the research, when the animal manifest severe or chronic pain, discomfort, distress or disability that cannot be relieved, it should be euthanized quickly and painlessly ${ }^{(6,15,21-22)}$.

Often, euthanasia is considered the main alternative for the management of pain in chronic models or of hard control ${ }^{(15)}$. A classic example is cancer pain in bone origin neoplasms or the oral cavity that is present in the early stages of evolution of the disease in humans and in induction animal models. The management of chronic pain is accomplished through ongoing management and progressive use of treatment with potent opioid formulations such as morphine. The administration of high doses of analgesics and disease progression may alter the research data, therefore, euthanasia appears as the main alternative for pain control ${ }^{(23)}$. Ethical principles aimed at the welfare of laboratory animals require consistent justifications and regard as highly questionable the experiments that cause severe pain or above the tolerance threshold of unanesthetized conscious animals(15).

We highlight that despite the extreme need of reproduction of biological models with animal for the advancement of science in health for the benefit of mankind, its implementation requires respect for the rights and the preservation of life without suffering of all animals. Ethical standards, knowledge and responsibility are the fundamentals for planning research with animal models.

The reflection on the way and the need for research on animals must be daily, particular and consider: Who does not know what he is looking for will not understand what he finds (Claude Bernard).

\section{Brazilian law}

In Brazil, Decree Law No. 6638/1979 was the first to set standards for teaching and scientific practice of vivisection of animals ${ }^{(24)}$. In 1998, the Law No. 9605/1998 or the law on environmental crimes was sanctioned, establishing as a crime and setting fines and penalties for those who commit acts of abuse and mistreatment, injure or maim animals of any species. The same category includes any person conducting painful and cruel experiments on living animals, even for educational or scientific purposes ${ }^{(25)}$.

Currently, the Law 11.794/2008, known as Arouca law establishes procedures for the scientific use of animals ${ }^{(26-27)}$. Determines the creation of CONCEA, formed by a multidisciplinary team of legal, advisory, deliberative and appeal character. The CONCEA turns mandatory credentialing and training CEUA in all institutions that use animals for educational or scientific purposes, and also manages the registration of experimental teaching protocols or procedures applicable to teaching and scientific research projects completed or ongoing across the country from information sent by CEUA ${ }^{(7)}$.

The Arouca law deals with conditions in the creation of biotherium, interventions recommended in the experimental protocol, special care as adequate sedation and analgesia, humane death, as established by CONCEA. Articles 17 and 18 define penalties for people or institutions who violate these regulations, including warnings, fines, temporary or permanent suspension and interdiction of activities ${ }^{(7)}$.

These federal provisions aimed at ensuring the federal definition of a careful planning of experiments, knowledge of the laws and guidelines of the country and the application of ethical principles for the handling of laboratory animals to safeguard the welfare and recognition of research publications in the scientific world ${ }^{(5,14,27)}$.

\section{Experimental research for nursing}

Basic science is defined as studies supporting professional training in biological, humanities and exact areas. It functions as a support for professional practice and conduction of applied researches ${ }^{(28)}$. The nurse trained in the development of experimental research seeks contributions to the assistance system and improving the ability to relate pathophysiological mechanisms of drug action and clinical aspects of patient ${ }^{(28-29)}$.

The new concept of interdisciplinarity in nursing research values the proposal of professional and academic interface since it enables the integration of information, data, techniques, tools, perspectives, concepts or theories from various disciplines or specialties to advance understanding or in the resolution of problems ${ }^{(30)}$.

\section{CONCLUSION}

The ethical premises and animal welfare led to the establishment of the rule of the three Rs - replacement, reduction and refinement. Experimental research with animals keep controlled environment to meet sanitary and genetic parameters to ensure uniformity in relation to environmental, genetic and experimental variables. A research priority is the welfare of laboratory animals, and their rights must be respected, according to Law No. $11.794 / 2008$, which establishes procedures for the scientific use of animals.

Experimental animal research may translate into unquestioned contribution to nurses and offers conceptual subsidies to relate pathophysiological mechanisms of drug action and clinical aspects of patients. 


\section{REFERENCES}

1. Hochman B, Nahas FX, Oliveira Filho RS, Ferreira LM. Desenho de pesquisa. Acta Cir Bras. 2005;20(Supl 2):2-9.

2. DaMatta RA. Modelos animais na pesquisa biomédica [editorial]. Sci Med. 2010; 20(3):210-11.

3. Monteiro R, Brandau R, Gomes WJ, Braille DM. Tendências em experimentação animal. Rev Bras Cir Cardiovasc. 2009;24(4):506-31.

4. Balls M. The origins and early days of the Three Rs concept [editorial]. Altern Lab Anim. 2009;37(3):255-65.

5. Miziara ID, Magalhães AT, Santos MD, Gomes EF, Oliveira RA. Research ethics in animal models. Braz J Otorhinolaryngol. 2012;78(2):128-31.

6. Damy SB, Camargo RS, Chammas RE, Figueiredo LF. Aspectos fundamentais da experimentação animal - aplicações em cirurgia experimental. Rev Assoc Med Bras. 2010;56(1):103-11.

7. Brasil. Lei n. 11.794 , de 8 de outubro de 2008. Dispõe sobre procedimentos para o uso científico de animais. Diário Oficial da União, Brasília, 9 out. 2008. Seção 1, p.1.

8. Mendes KDS, Silveira RCCP, Galvão CM. Revisão integrativa: método de pesquisa par incorporação de evidências na saúde e na enfermagem. Texto Contexto Enferm. 2008;17(4):758-64.

9. Ferreira LM, Hochman B, Barbosa MVJ. Modelos experimentais em pesquisa. Acta Cir Bras. 2005;20(2):28-34.

10. Baumans V. Use of animals in experimental research: an ethical dilemma? Gene Ther. 2004;11(Suppl 1):S64-6.

11. Ferdowsian HR, Beck N. Ethical and scientific considerations regarding animal testing and research. PloS One. 2011;6(9):e24059.

12. Ramalli Jr EL, Ho W, Alves M, Rocha EM. Progress in animal experimentation ethics: a case study from a Brazilian medical school and from the international medical literature. Acta Cir Bras. 2012;27(9):659-63.

13. Balls M. Reduction. Altern Lab Anim. 2013;41(2):P24-5.

14. Eckelman WC, Kilboum MR, Joyal JL, Labiris R, Valliant JF. Justifying the number for each experiment. Nucl Med Biol. 2007;34(3):229-32.

15. Carbone L. Pain in laboratory animals: the ethical and regulatory imperatives. PloS One. 2011;6(9):e21578.

16. Schnaider TB, Souza C. Aspectos éticos da experimentação animal. Rev Bras Anestesiol. 2003;53(2):278-85.
17. U. S. National Institute for Health; Department of Agriculture. Consensus recommendations on effective institutional Animal Care and Use Committees. Lab Anim Sci. 1987;37(n. spec):11-3.

18. Guillen J. FELASA guidelines and recommendations. J Am Assoc Lab Anim Sci. 2012;51(3):311-21.

19. Shehnaz SI, Agarwal AK. Animal ethics training for postgraduates in medical schools in India: catch them young! Altern Lab Anim. 2013;41(1):P2-4.

20. Tiplady C. Animal use in veterinary education-the need for a fourth R: respect. Altern Lab Anim. 2012;40(5):P5-6.

21. Giraldo LFG, Zulunga CG. Bioética em la experimentación científica com animales: cuestión de regulamentación o de actitud humana. Rev Lasallist Investig. 2012; 9(1):159-66.

22. Phillips $C$. The ethics of using laboratory animals to develop medicines for lifestyle diseases. Altern Lab Anim. 2013;41(2):P22-3.

23. Pacharensak $C$, Beitz A. Animals models of cancer pain. Comp Med. 2008; 58(3):220-33.

24. Brasil. Lei n. 6638, de 8 de maio de 1979. Dispõe sobre normas para prática didático-científica de vissecção de animais e dá outras providências. Dário oficial da União, Brasília, 10 maio 1979. Seção1, p.6537.

25. Brasil. Lei n. 9605, de 12 de fevereiro de 1998. Dispõe sobre as sanções penais e administrativas derivadas de condutas e atividades lesivas ao meio ambiente e outras providências. Diário Oficial da União, Brasília, 13 fev. 1998. Seção 1, p.1.

26. Machado CJS, Filipecki ATP, Teixeira MO, Klein HE. A regulação do uso de animais no Brasil do século XX e o processo de formação do atual regime aplicado à pesquisa biomédica. Hist Ciênc Saúde Manguinhos. 2010;17(1):87-105.

27. Pimenta LG, Silva AL. Ética e experimentação animal. Acta Cir Bras. 2001;16(4): 255-60.

28. Cárnio EC. Basic sciences and nursing [editorial]. Rev Latino Am Enferm. 2011;19(5):1061-2.

29. Alves LMM, Nogueira MS, Godoy S, Cárnio EC. Pesquisa básica na enfermagem. Rev Latino Am Enferm. 2004;12(1):122-7.

30. Oliveira MAC. Interdisciplinarity in nursing education and research [editorial]. Rev Esc Enferm USP [Internet]. 2012 [cited 2013 May 22];46(2):1-2. Available from: http://www. scielo.br/pdf/reeusp/v46n2/en_a01v46n2.pdf

\section{Support}

São Paulo Research Foundation - FAPESP (Process n 2011/24028-6). 